\title{
Initial intravenous fluid prescription in general paediatric in-patients aged $>28$ days and $<18$ years: consensus statements
}

\author{
Lettie CK Leung *, LY So, YK Ng, Winnie KY Chan, WK Chiu, CM Chow, SY Chan, KC Chan; \\ for the IVF Working Group
}

\section{A B S T R A C T}

Intravenous fluid (IVF) prescription has often been an 'assumed' skill in hospital-based paediatric practice, with little evidence-based guidance. Traditionally prescribed hypotonic fluids were responsible for many iatrogenic, hyponatraemiarelated morbidity and mortality. Robust evidence is available to support recent guidelines that isotonic fluids are the most appropriate maintenance IVF for most hospitalised children. However, many other aspects of IVF prescription still lack evidence. Thus, an IVF Working Group was formed in 2016 under the Hospital Authority Paediatric Coordinating Committee to review IVF guidelines for local application, with the aim to provide guidance for initial IVF prescription and subsequent monitoring of paediatric in-patients in Hong Kong. Published randomised controlled trials, IVF guidelines, and practices of reputable children's hospitals up to December 2019 were reviewed. Local survey findings and practical realities were considered. Extracted evidence and draft recommendations were presented to the group, using a consensus approach in areas where evidence was unavailable. After further input from designated reviewers, an IVF clinical pathway was finalised in November 2019 and endorsed by the Paediatric Clinical Coordinating Committee. This article represents an explanatory discussion of the pathway, with consensus statements established by Working Group members at the final meeting in June 2020. The consensus statements emphasise that
IVF should be prescribed with the same care and consideration as medications, based on each patient's pathophysiology. Evidence is presented regarding the use of isotonic maintenance fluid, comparing $0.9 \%$ sodium chloride with balanced solutions. These eight statements provide localised guidance for paediatricians in initial IVF prescription but do not replace clinical judgement.

Hong Kong Med J 2021;27:276-86

https://doi.org/10.12809/hkmj209010

${ }^{1}$ LCK Leung *, FRCP, FHKCPaed

${ }^{2}$ LY So, FHKCPaed, FRCPCH

${ }^{3} \mathrm{YK} \mathrm{Ng}$, FHKCPaed

${ }^{4}$ WKY Chan, FHKCPaed, FRCPCH

${ }^{5}$ WK Chiu, FHKCPaed, FRCPCH

${ }^{6} \mathrm{CM}$ Chow, FHKCPaed, FHKAM (Paediatrics)

${ }^{4}$ SY Chan, RN, MSc (HSM)

${ }^{7}$ KC Chan, FHKCPaed, FRCPCH

Department of Paediatrics, Kwong Wah Hospital, Hong Kong

${ }^{2}$ Department of Paediatrics and Adolescent Medicine, Pamela Youde Nethersole Eastern Hospital, Hong Kong

${ }^{3}$ Department of Paediatrics and Adolescent Medicine, Queen Mary Hospital. Hong Kong

${ }^{4}$ Department of Paediatrics, Queen Elizabeth Hospital, Hong Kong

${ }^{5}$ Department of Paediatrics and Adolescent Medicine, United Christian Hospital, Hong Kong

${ }^{6}$ Department of Paediatrics, Prince of Wales Hospital, Hong Kong

Department of Paediatrics and Adolescent Medicine, Alice Ho Miu Ling Nethersole Hospital, Hong Kong

* Corresponding author: leungckl@ha.org.hk

\section{Introduction}

The prescription of intravenous fluid (IVF) is an essential management modality in hospital paediatrics. The traditional practice of administering hypotonic maintenance IVF $(0.18-0.3 \%$ sodium chloride $[\mathrm{NaCl}])$ was based on the Holliday-Segar formula published in 1957'; being calculated from estimated fluid and electrolyte requirements based on milk intake in healthy children. Holliday-Segar formula for maintenance fluid in 24 hours is calculated as below: (1) body weight (BW) of $\leq 10 \mathrm{~kg}: 100 \mathrm{~mL} / \mathrm{kg}$; (2) BW of 11-20 kg: $1000 \mathrm{~mL}+50 \mathrm{~mL} / \mathrm{kg}$ for each $\mathrm{kg}$ over 10; (3) BW of >20 kg: $1500 \mathrm{~mL}+20 \mathrm{~mL} / \mathrm{kg}$ for each $\mathrm{kg}$ over 20 . However, since the $1990 \mathrm{~s}$, more than
100 cases of hyponatremia-related iatrogenic death or permanent neurologic impairment have been reported; nearly all studies have shown that hospitalacquired hyponatremia is related to hypotonic fluid administration. ${ }^{2}$ This is related to the high incidence of non-osmotic stimuli of antidiuretic hormone (SIADH) in sick children, which leads to an impaired ability to excrete free water.

Since the 1990s, there have been many randomised controlled trials (RCTs) and metaanalyses comparing hypotonic and isotonic fluids in children initially in postoperative and paediatric intensive care unit settings, but recently also in general paediatric settings. Based on the available 
high-quality evidence, the 2015 NICE guideline ${ }^{3}$ and the American Academy of Pediatrics maintenance fluid guidelines ${ }^{4}$ have strongly recommended the use of isotonic maintenance IVF for most paediatric patients aged $>28$ days.

In Hong Kong, there are no local guidelines regarding IVF prescription in children. A 2016 informal survey of 11 acute paediatric units within the Hospital Authority showed that dextrosecontaining $0.3 \% \mathrm{NaCl}$ and $0.45 \% \mathrm{NaCl}$ were the main maintenance fluids used; no units routinely used isotonic fluids. Our recent survey ${ }^{5}$ of more than 60000 hospital admissions of children aged 1 month to 18 years in the year 2015 also showed variations among hospitals in terms of IVF practices. Hyponatraemia commonly occurred in $8.8 \%$ of admissions. In total, 110 patients exhibited true, nondilutional severe hyponatraemia $(<127 \mathrm{mmol} / \mathrm{L})$; this was hospital-acquired in 22 patients (presumably related to hypotonic IVF) and some of them exhibited neurological complications. In this context, the current practice statement is intended to guide all clinicians who prescribe IVF in children, encouraging methodological prescription practices to minimise fluid and electrolyte morbidities.

\section{Basic intravenous fluid concepts}

\section{Osmolality versus tonicity}

Osmolality is the concentration of a solution expressed as the number of solute particles per kilogram of solution (plasma). Tonicity is a measure of the effective osmolality between two fluid compartments separated by a semi-permeable membrane (eg, a cell membrane). For our purposes, tonicity refers to the sodium concentration of the fluid. Dextrose does not affect tonicity because it is rapidly metabolised in the blood stream.

\section{Normal saline versus balanced solution}

The compositions of available IVF preparations in Hong Kong are detailed in Table 1 . Normal saline $(0.9 \% \mathrm{NaCl})$ may not be as "normal" as its name suggests. Compared with plasma, $0.9 \% \mathrm{NaCl}$ has higher sodium ( $\mathrm{Na} 154$ vs $140 \mathrm{mmol} / \mathrm{L}$ ) and chloride (Cl 154 vs $103 \mathrm{mmol} / \mathrm{L}$ ) concentrations; moreover, large volumes of $0.9 \% \mathrm{NaCl}$ lead to hyperchloraemic acidosis in adults and children. ${ }^{6}$

Balanced solutions are solutions with more physiologically appropriate electrolyte compositions (Table 1). They contain buffers with mild alkalinising effects. For example, Hartman's and Ringer's lactate solutions contain sodium lactate, which is metabolised into bicarbonate by the liver. PlasmaLyte 148 contains acetate, which is similarly metabolised (within 15 minutes) by the liver and skeletal muscle. Acetate metabolism has several advantages: it is not entirely dependent on hepatic

\section{年齡 28 天以上至 18 歲以下的普通兒科住院患者 的初始靜脈輸液處方共識聲明

\author{
梁竹筠、蘇樂儀、吳耀基、陳桂如、趙華強、周中武、 \\ 陳倩儀、陳國超
}

靜脈輸液處方通常是醫院兒科實踐中的「假定」技能, 幾乎沒有循證 指導。傳統規定的低滲液導致許多醫源性、低鈉血症相關的發病和死 亡。不少強而有力的證據支持近期相關指引, 即等滲液是大多數住院 兒童最合適的靜脈輸液維持治療。然而, 靜脈輸液處方的多方面仍然 缺乏證據。因此, 醫院管理局兒科協調委員會於2016年成立靜脈輸液 工作小組, 以檢討本地應用的指引, 旨在為香港兒科住院病人的靜脈 輸液處方和後續監測提供指導。回顧截至2019年12月已發表的隨機對 照試驗、靜脈輸液指南及知名兒童醫院的做法, 並考慮本地調查結果 和實際情況。提取的證據和建議草案交給工作小組, 在證據不可用的 領域採用共識方法。在指定審查員給予進一步意見後, 在 2019 年11月 最終確定靜脈輸液臨床路徑, 並得到兒科臨床協調委員會的批准。本 文對這個靜脈輸液臨床路徑作解釋性討論, 以及發表工作小組成員在 2020 年6月的最後一次會議上建立的共識聲明。共識聲明強調應根據 個別患者的病理生理情況作仔細的考慮才作合適的靜脈輸液處方。本 文提供有關使用等滲維持液的證據, 將 $0.9 \% \mathrm{NaCl}$ 與平衡溶液進行比 較。這八項聲明為兒科醫生的初始靜脈輸液處方提供指導, 但不能取 代臨床判斷。

function, it is preserved in severe shock, and it will not disrupt reported serum lactate levels. Furthermore, Hartman's and Ringer's lactate solutions contain calcium, which may contribute to extravasation and cause incompatibility with blood or drugs such as cefotaxime. In contrast, Plasma-Lyte 148 contains magnesium, for which limited drug compatibility information is available.

There is increasing evidence that $0.9 \% \mathrm{NaCl}$ is associated with increased rates of mortality, acute kidney injury, metabolic acidosis, and coagulopathy in critically ill adults ${ }^{7,8}$ and acute kidney injury in non-critically ill adults, ${ }^{9}$ compared with balanced solutions. These effects have been attributed to its supraphysiologic chloride concentration, which causes renal vasoconstriction. ${ }^{6,10}$ In children with septic shock, hyperchloraemia is also associated with acute kidney injury and mortality ${ }^{11-13}$; this implication will be discussed later.

\section{Methods}

After publication of the NICE IVF guideline, an IVF Working Group (ie, the IVFWG) was formed in June 2016 under the Evidence-based Practice Working Group of the Hospital Authority Paediatric Clinical Coordinating Committee to form recommendations regarding maintenance fluid prescription. A retrospective survey of hyponatraemia with a focus on IVF practices was commissioned and published $^{5}$; lessons from the survey were taken into consideration. Additionally, a literature search was 
TABLE I. Compositions of commonly used intravenous fluid preparations available in Hong Kong

\begin{tabular}{|c|c|c|c|c|c|c|c|c|}
\hline Fluids & $\begin{array}{l}\text { Tonicity } \\
\text { (ignores } \\
\text { glucose) }\end{array}$ & $\begin{array}{l}\text { Osmolarity } \\
\text { (mOsmol/L) }\end{array}$ & $\begin{array}{c}\mathrm{Na}^{+} \\
(\mathrm{mmol} / \mathrm{L})\end{array}$ & $\begin{array}{c}\mathrm{K}^{+} \\
(\mathrm{mmol} / \mathrm{L})\end{array}$ & $\begin{array}{c}\mathrm{Cl}^{-} \\
(\mathrm{mmol} / \mathrm{L})\end{array}$ & $\begin{array}{l}\text { Dextrose } \\
\text { (mmol/L) }\end{array}$ & Remarks & $\begin{array}{c}\text { Cost } \\
\text { implications }\end{array}$ \\
\hline Plasma & Reference & 288 & 140 & 4.5 & 103 & - & $\begin{array}{l}\mathrm{Ca} 2.5 \mathrm{mmol} / \mathrm{L} \\
\mathrm{Mg} 1.25 \mathrm{mmol} / \mathrm{L} \\
\text { buffer } 24 \mathrm{mmol} / \mathrm{L} \\
\text { (bicarbonate) }\end{array}$ & \\
\hline \multicolumn{9}{|l|}{$0.9 \% \mathrm{NaCl}$} \\
\hline $0.9 \% \mathrm{NaCl}$ & Isotonic & 308 & 154 & 0 & 154 & 0 & & \\
\hline $0.9 \% \mathrm{NaCl}+5 \%$ dextrose & Isotonic & 560 & 154 & 0 & 154 & 252 & & \\
\hline $0.9 \% \mathrm{NaCl}+20 \mathrm{mmol} / \mathrm{L} \mathrm{KCl}$ & Isotonic & 348 & 154 & 20 & 174 & 0 & & \\
\hline \multicolumn{9}{|l|}{ Balanced solutions } \\
\hline Hartmann's solution & Isotonic & 278 & 131 & 5 & 111 & 0 & $\begin{array}{c}\mathrm{Ca} 2 \mathrm{mmol} / \mathrm{L} \\
\text { lactate } 29 \mathrm{mmol} / \mathrm{L}\end{array}$ & \\
\hline Ringer's lactate & Isotonic & 273 & 130 & 4 & 109 & 0 & $\begin{array}{l}\text { Ca } 1.35 \mathrm{mmol} / \mathrm{L} \\
\text { lactate } 28 \mathrm{mmol} / \mathrm{L}\end{array}$ & \\
\hline Ringer's lactate $+5 \%$ dextrose & Isotonic & 525 & 130 & 4 & 109 & 252 & $\begin{array}{l}\mathrm{Ca} 1.35 \mathrm{mmol} / \mathrm{L} \\
\text { lactate } 28 \mathrm{mmol} / \mathrm{L}\end{array}$ & \\
\hline Plasma-Lyte 148 (pH 7.4) & Isotonic & 294 & 140 & 5 & 98 & 0 & $\begin{array}{l}\mathrm{Mg} 1.5 \mathrm{mmol} / \mathrm{L}, \\
\text { acetate, and } \\
\text { gluconate }\end{array}$ & \\
\hline Plasma-Lyte $148+5 \%$ glucose & Isotonic & 572 & 140 & 5 & 98 & 252 & $\begin{array}{l}\mathrm{Mg} 1.5 \mathrm{mmol} / \mathrm{L}, \\
\text { acetate, and } \\
\text { gluconate }\end{array}$ & $\begin{array}{l}\text { Costs } \sim \mathrm{HK} \$ 20 / \mathrm{L} \\
\text { more than } 0.9 \% \\
\mathrm{NaCl} 5 \% \text { dextrose }\end{array}$ \\
\hline \multicolumn{9}{|l|}{ Hypotonic solutions } \\
\hline $0.45 \% \mathrm{NaCl}+5 \%$ dextrose & Hypotonic & 406 & 77 & 0 & 77 & 252 & & \\
\hline $\begin{array}{l}0.45 \% \mathrm{NaCl}+5 \% \text { dextrose }+ \\
20 \mathrm{mmol} / \mathrm{L} \mathrm{KCl}\end{array}$ & Hypotonic & 446 & 77 & 20 & 97 & 252 & & \\
\hline
\end{tabular}

Abbreviations: $\mathrm{Ca}=$ calcium; $\mathrm{Cl}^{-}=$chloride; $\mathrm{K}^{+}=$potassium; $\mathrm{KCl}=$ potassium chloride; $\mathrm{Mg}=$ magnesium; $\mathrm{Na}^{+}=$sodium; $\mathrm{NaCl}=$ sodium chloride

performed using the keywords ("intravenous fluid" OR "isotonic" OR "hypotonic" OR "maintenance fluid") AND ("child") in MEDLINE and EMBASE databases; results from January 2000 to December 2019 were collected. All RCTs and meta-analyses regarding maintenance IVF were reviewed. For our review (ie, maintenance fluids in general paediatric settings), we only included paediatric RCTs where medical patients constituted more than $50 \%$ of the study population. We excluded studies in which surgical or intensive care patients comprised the majority of patients, as well as studies in which IVF served both rehydration and maintenance purposes. The certainty of evidence and strength of each recommendation were determined in accordance with GRADE methodology (https:// www.gradeworkinggroup.org/). Extracted evidence was presented to the IVFWG. In areas for which the evidence level was high, clear recommendations were made. In areas for which trial data were lacking, the preferred treatment was determined by a consensus approach based on the knowledge and clinical experience of the IVFWG members.

The first draft recommendations were presented to IVFWG members in February 2019. After publication of the American Academy of Pediatrics guideline 4 in December 2018, IVF guidelines were amended by many reputable international children's hospitals. These amended guidelines were also used as reference information; their applicability to patients in Hong Kong were further discussed within the group. The consensus document was submitted to a panel of five external reviewers chosen by the Evidence-based Practice Working Group to widen input from all subspecialty sectors. In accordance with the reviewers' comments, a clinical pathway was finalised in November 2019 (Fig) and endorsed by the Paediatric Clinical Coordinating Committee. This article represents an explanatory discussion of the pathway, with consensus statements established by IVFWG members at the final meeting in June 2020. In this article, each statement includes an indication of whether it was established on the basis of evidence or IVFWG member consensus. 


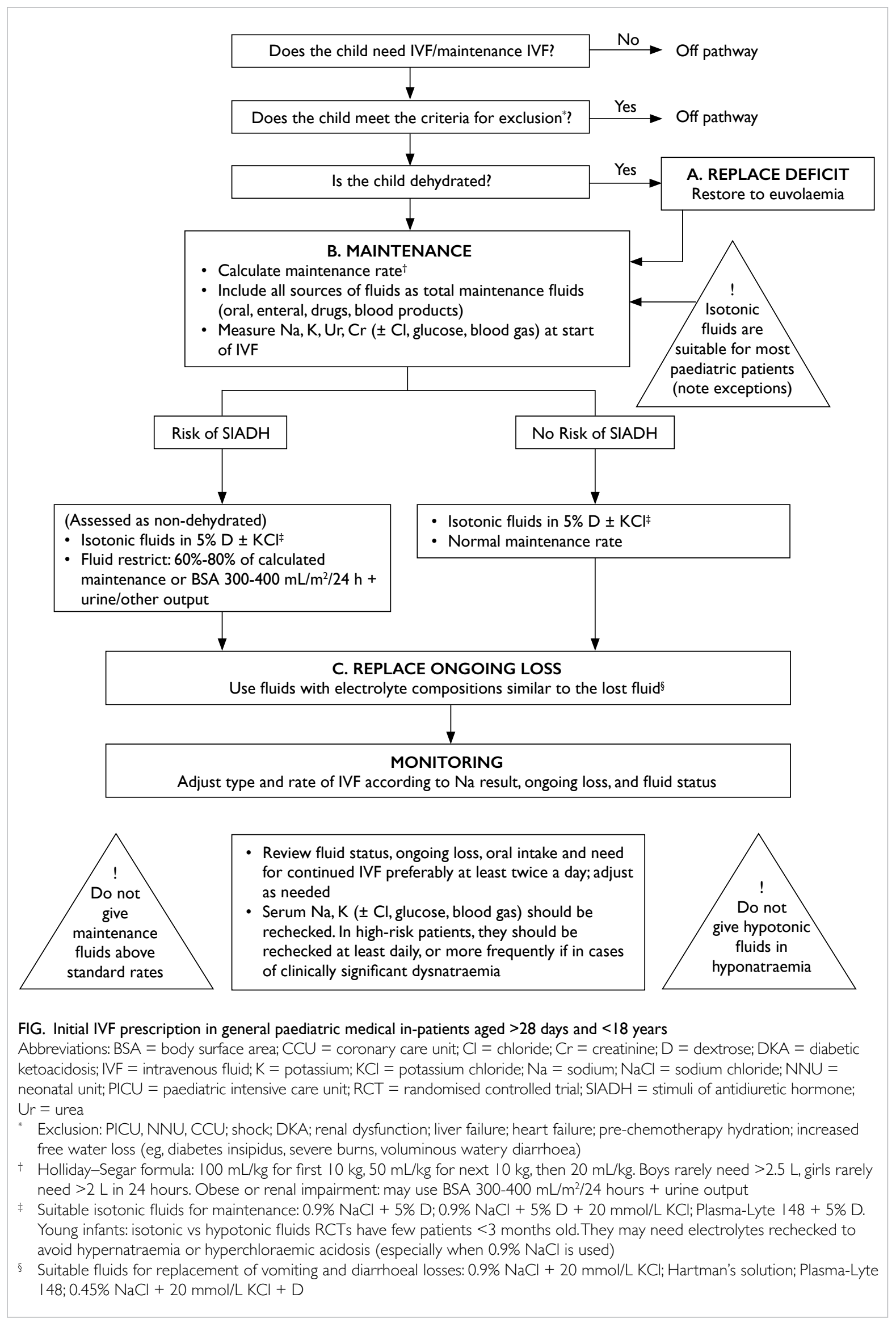




\section{Scope of consensus statements}

These consensus statements aim to facilitate initial IVF prescription (ie, prescription principles, with a focus on maintenance fluids) and subsequent monitoring for general paediatric in-patients. They are not meant to replace clinical judgement, nor do they represent a comprehensive discourse regarding fluid resuscitation, specific conditions, or treatment of dysnatraemia.

\section{Target population}

The target population for these statements comprises children aged $>28$ days to $<18$ years who have been admitted to a general paediatric ward for medical conditions. Based on the exclusion criteria of the majority of prospective studies of maintenance fluids, Table 2 lists patients excluded from guidance in these statements. Their IVF needs should be individually assessed (see Statement 2).

\section{Consensus statements}

Statement 1. Intravenous fluid should be administered only when the enteral route is considered inappropriate or inadequate; IVF should be discontinued once enteral route can be substituted. (Consensus)

Enteral fluid administration is always safer and preferable because the child can autoregulate the amount of ingested fluid. The indication and continued need for IVF should be reviewed regularly; IVF should be stopped when enteral intake is adequate. If the patient is unable to increase enteral intake and has been receiving IVF for 5 days, parenteral nutrition should be considered.

\section{Statement 2. Intravenous fluid should be prescribed with the same care and consideration as used for medication. Individual clinical situations must be assessed, with specific attention to the patient's volume status, pathophysiological and biochemical state. (Consensus)}

No single solution can provide maintenance water and electrolyte needs for all children because needs vary among individuals and disease states. It is crucial to understand the pathophysiological state of a particular patient (Table $3^{14}$ ). Before prescribing, clinicians should ask: Why am I prescribing IVF? What disease state, abnormal volume status, and water or electrolyte imbalance am I starting with? Based on these considerations, which type and rate of fluid should I choose? How will I monitor the effects and side-effects of my treatment, with the awareness that requirements may change as the patient's condition evolves?
TABLE 2. Criteria for exclusion from the intravenous fluid consensus statements and clinical pathway

- Patients in neonatal units, intensive care units

- Shock

- Endocrine electrolyte disturbances: diabetic ketoacidosis, hyperglycaemic hyperosmolar state, adrenal insufficiency

- Renal impairment, nephrotic syndrome, renal tubular disorders

- Liver failure

- Heart failure

- Pre-chemotherapy hydration

- Known or suspected inborn errors of metabolism

- Increased free water loss (eg, renal concentrating defects, diabetes insipidus, voluminous watery diarrhoea, severe burns)

Statement 3. When IVF is prescribed, the three components of prescription (deficit replacement, maintenance, and management of ongoing loss) should be considered separately. (Consensus)

The goal of IVF is maintenance of fluid and electrolyte homeostasis. Hypovolaemia is a physiological stimulus for antidiuretic hormone release; therefore, deficits should be replaced to achieve euvolaemia. Patients then require IVF to maintain their ideal volume status, with continued clinical and biochemical monitoring of ongoing loss. These three components require different considerations of fluid types and rates. Fluids intended to replace deficits or ongoing losses may be co-administered with maintenance fluids for easier adjustments.

A clinical pathway depicting initial IVF prescription for general paediatric in-patients is illustrated in the Figure.

Statement 4. Replacement of fluid deficit should usually be with non-glucosecontaining isotonic fluids at the appropriate rate. (Consensus)

Deficit replacement fluids restore hydration by replacing fluids already lost. Volume deficits are isotonic deficits; therefore, they should normally be replaced with isotonic fluids at the appropriate rate for the patient's particular pathophysiological state. For example, 10 to $20 \mathrm{~mL} / \mathrm{kg} /$ hour for 2 to 4 hours may be appropriate for a normonatraemic dehydrated child with gastroenteritis without shock. ${ }^{15,16}$ The rate should be slower in patients with pre-existing cardiac or renal disease; the deficit replacement volume should be administered over a longer period (eg, 48 hours) in patients with diabetic ketoacidosis or hypernatraemic dehydration.

4.1 Regarding evidence for fast $(20-60 \mathrm{~mL} / \mathrm{kg}$ in 
TABLE 3. Understanding the patient's pathophysiology: conditions requiring special considerations when intravenous fluids are prescribed (modified from Moritz et $\mathrm{al}^{14}$ )

Age, prematurity

Obesity (consider body surface area for calculation)

Baseline volume status

Baseline water or electrolyte imbalance (if results are available)

Free-water restriction for conditions of SIADH

$\square$ Pain and stress, nausea, and vomiting

$\square$ Hypoxaemia and hypercapnia

$\square$ Hypoglycaemia

$\square$ Fever, inflammation

$\square$ Cancer

$\square$ Pulmonary disease (eg, pneumonia, asthma, bronchiolitis, tuberculosis)

$\square$ Central nervous system disease (eg, meningitis, encephalitis, brain tumours, head injury, cerebritis, subarachnoid haemorrhage)

$\square$ Perioperative state

$\square$ Trauma

Medications

- Drugs causing nausea

- Central release of vasopressin (narcotics, barbiturates, MDMA [ie, "ecstasy"])

- Enhancement of renal effects of vasopressin (NSAIDs, carbamazepine)

- Selective serotonin reuptake inhibitors

- Chemotherapeutic agents: cyclophosphamide, vincristine

Fluid and sodium restriction for oliguric/oedematous states

$\square$ Oliguric kidney disease (eg, acute tubular necrosis, acute glomerulonephritis, end-stage renal disease)

$\square$ Heart failure

$\square$ Cirrhosis

Nephrotic syndrome

Increased free water requirements

$\square$ Hypernatraemic situations of free water deficit (eg, hypernatraemic dehydration) or salt gain (eg, restricted access to water or impaired thirst mechanism, improperly mixed formula)

$\square$ Renal free water loss: central or nephrogenic diabetes insipidus, renal diseases (eg, tubulointerstitial diseases, renal dysplasia, obstructive or reflux nephropathy), tubular diseases (eg, Bartter's), systemic conditions (eg, hypercalcaemia, hypokalaemia, amyloidosis, sarcoidosis, lithium use)

$\square$ Extrarenal free water loss: severe burns, voluminous diarrhoea

Increased sodium and water requirements from renal loss

$\square$ Diuretic phase of acute tubular necrosis, post-obstructive diuresis

$\square$ Osmotic diuresis from diabetes mellitus or mannitol

$\square$ Adrenal insufficiency

Cerebral salt wasting

Abbreviations: MDMA = 3,4-methylenedioxymethamphetamine; NSAIDs = nonsteroidal anti-inflammatory drugs; $\mathrm{SIADH}=$ syndrome of inappropriate antidiuretic hormone secretion

Water loss exceeds sodium loss

1-2 hours) versus slow (in 2-4 hours) rates of fluid replacement in patients with acute gastroenteritis, available RCTs have shown heterogeneous results and have generally been conducted in resource-limited settings. ${ }^{17}$ Fast rates of rehydration have not demonstrated clearly superior results. Considering recent concerns regarding aggressive fluid expansion, more research is warranted before guidelines can be established.

4.2 Notably, $0.9 \% \mathrm{NaCl}$ has been the traditional fluid of choice for both volume resuscitation and deficit replacement. As previously mentioned, there are concerns that high volumes of $0.9 \%$ $\mathrm{NaCl}$ cause hyperchloraemia-related adverse effects in critically ill adults and children. ${ }^{6}$ Some paediatric anaesthetist guidelines ${ }^{18,19}$ favour administration of balanced fluids over $0.9 \%$
$\mathrm{NaCl}$ for resuscitation/replacement. However, there is no evidence thus far from small studies in non-critically ill children that balanced solutions are superior. ${ }^{20,21}$ It may be prudent for clinicians to monitor for hyperchloraemia and consider the use of more physiologically appropriate solutions in sick children. ${ }^{22}$

\section{Statement 5. Initial IVF and maintenance IVF types: most children aged $>28$ days to $<18$ years should receive isotonic solutions with appropriate potassium chloride and dextrose as maintenance IVF. (High-quality evidence, strong recommendation)}

Intravenous fluid administration is intended to meet anticipated water and electrolyte needs from insensible losses and urinary output. When 
prescribing initial IVF, clinicians should consider that most hospitalised children are at risk of osmotic (appropriate) and non-osmotic (inappropriate) antidiuretic hormone secretion (Table 3), causing an inability to excrete free water through dilute urine. This puts the child at risk of positive water balance and hyponatraemia when hypotonic fluids are administered.

5.1 Earlier RCTs regarding fluid tonicity were mainly in surgical and paediatric intensive care unit patients. Our literature search revealed high-quality evidence from 10 RCTs involving general paediatric in-patients, indicating that isotonic fluids significantly reduce the risk of hyponatraemia compared with hypotonic fluids (including $0.45 \% \mathrm{NaCl}$ ). Table $4^{23-32}$ lists the characteristics and GRADE evidence levels of these studies. Most RCTs used $0.9 \% \mathrm{NaCl}$ with $20 \mathrm{mmol} / \mathrm{L}$ potassium chloride $(\mathrm{KCl})$ in the isotonic arm, whereas the PIMS trial, ${ }^{25}$ which included >690 children used Plasma-Lyte 148 . Eight of the 10 studies included $0.45 \% \mathrm{NaCl}$ in the hypotonic fluid arm. Study appraisal of these RCTs (total 1945 patients) showed that eight of the 10 were methodologically sound (GRADE evidence level $\geq 3$ ). Hence, highquality evidence indicates that hypotonic fluids (including $0.45 \% \mathrm{NaCl}$ ) carry a significantly greater risk of hospital-acquired hyponatraemia (relative risk=3.7-6.5), as well as a risk of failed sodium status improvement in patients with baseline hyponatraemia.

5.2 Regarding potential harm, there is no evidence from these studies that isotonic maintenance fluids increase the risk of hypernatraemia. However, other side-effects (eg, fluid overload, hypertension, and hyperchloraemic acidosis) have not been sufficiently evaluated. This highlights the importance of continuous monitoring.

5.3 Three isotonic fluids containing 5\% dextrose (D5) are available in Hong Kong: $0.9 \% \mathrm{NaCl}$ D5, Ringer's lactate D5 balanced solution, and Plasma-Lyte 148 D5 balanced solution (compositions listed in Table 1). Guidelines adopting robust methodologies ${ }^{3,4}$ have not indicated a preference for any particular isotonic fluid composition; however, Children's Hospital Colorado guidelines indicate a preference for balanced solutions (rather than $0.9 \% \mathrm{NaCl}$ ) as maintenance fluid for all age ranges, citing the need to monitor for hyperchloraemic acidosis with 'unbalanced' $0.9 \% \quad \mathrm{NaCl} .{ }^{33}$ However, because there is a lack of direct comparative studies, this recommendation is more opinionthan evidence-based.

5.4 A note of caution is needed regarding the selection of isotonic fluids in young infants because most $\mathrm{RCTs}$ recruited infants from age 3 months; all RCTs contained few young infant patients. Because of their immature kidneys, young infants may require electrolyte monitoring to ensure hypernatraemia and/or hyperchloraemic acidosis do not occur, especially when $0.9 \% \mathrm{NaCl}$ is used. Thus, we suggest using dextrose-containing balanced solutions with lower $\mathrm{NaCl}$ content as maintenance IVF for patients aged 1 to 3 months.

5.5 When maintenance IVF treatment is considered for older infants, the widely available $0.9 \% \mathrm{NaCl}$ D5 is a suitable choice, especially if the treatment is supplementary or will be administered for short-term use. However, because of its high chloride content, clinicians should consider the potential risk of hyperchloraemic acidosis when $0.9 \% \mathrm{NaCl} \mathrm{D} 5$ is used in large volumes or for long durations, particularly in sick patients.

5.6 The slightly more expensive (HK\$20/L more) Plasma-Lyte 148 D5 balanced solution is also a suitable isotonic solution for general use, especially in sick patients or patients exhibiting shock because of its lower chloride content. The mild alkalinising effect of this solution may benefit patients with acidaemia, although caution is needed when the solution is used in patients with hypocalcaemia or metabolic alkalosis. Plasma-Lyte 148 D5 balanced solution contains potassium at physiologically appropriate concentrations which can provide maintenance needs, but it should not be used in patients with hyperkalaemia. ${ }^{34}$

5.7 In the uncommon situations involving free water deficit, excessive non-renal or renal free water, or hypotonic fluid loss (Table 3), hypotonic fluids may be needed. These situations are usually associated with hypernatraemia, which should be corrected slowly (at a concentration $<10 \mathrm{mmol} / \mathrm{L} / 24$ hours). Paired serum and urinary osmolarity and electrolyte monitoring are helpful in these situations.

5.8 There is no evidence-based recommendation regarding the addition of $\mathrm{KCl}$, although many guidelines suggest the addition of 10 to $20 \mathrm{mmol} / \mathrm{L} \mathrm{KCl}$ to maintenance IVF after confirmation of normal serum potassium and creatinine levels, as well as confirmation that there is no risk of renal impairment. Potassium supplementation is important when there is a delay in reinitiation of oral intake. Balanced solutions generally do not require additional potassium supplementation, ${ }^{33}$ though their physiological $\mathrm{KCl}$ concentration is inadequate to treat hypokalaemia. 
TABLE 4. Randomised controlled trials concerning tonicity of maintenance IVF among general paediatric in-patients

\begin{tabular}{|c|c|c|c|c|}
\hline Study type and size & Intervention fluids and rate & Population and other details & Findings & $\begin{array}{l}\text { GRADE evidence level (lowest } \\
1 \text { to highest } 4 \text { ) }\end{array}$ \\
\hline $\begin{array}{l}\text { Kannan et al, } 2010^{23} \\
\text { - Paediatrics ward in } \\
\text { university hospital, } \\
\text { India } \\
\text { - } \mathrm{n}=167\end{array}$ & $\begin{array}{l}\text { 1. } 0.9 \% \mathrm{NaCl} / 5 \% \mathrm{D} \text { at standard } \\
\text { rate } \\
\text { 2. } 0.18 \% \mathrm{NaCl} / 5 \% \mathrm{D} \text { at } \\
\text { standard rate } \\
\text { 3. } 0.18 \% \mathrm{NaCl} / 5 \% \mathrm{D} \text { at } 2 / 3 \text { rate }\end{array}$ & $\begin{array}{l}\text { - Age } 3 \text { months to } 12 \text { years } \\
\text { - Broad-range paediatrics } \\
\text { diagnoses } \\
\text { - Mean IVF duration, } 60 \text { hours }\end{array}$ & $\begin{array}{l}\text { - } 0.9 \% \mathrm{NaCl} \text { : eightfold less likely to } \\
\text { exhibit hyponatraemia ( } \mathrm{RR}=0.12 \text {, } \\
95 \% \mathrm{Cl}=0.016-0.93) \\
\text { - No hypernatraemia }\end{array}$ & $\begin{array}{l}\text { - Bias: no } \\
\text { - Imprecision: no } \\
\text { - Indirectness: yes } \\
\text { - Final GRADE evidence level: } 3\end{array}$ \\
\hline $\begin{array}{l}\text { Friedman et al, } 2015^{24} \\
\text { - Paediatrics unit in } \\
\text { children's hospital, } \\
\text { Toronto, Canada } \\
\text { - } \mathrm{n}=110\end{array}$ & $\begin{array}{l}\text { 1. } 0.9 \% \mathrm{NaCl} / 5 \% \mathrm{D} \\
\text { 2. } 0.45 \% \mathrm{NaCl} / 5 \% \mathrm{D} \\
\text { - IV } \pm \text { oral routes, standard } \\
\text { rates }\end{array}$ & $\begin{array}{l}\text { - Age } 1 \text { month to } 18 \text { years } \\
\text { - Broad-range paediatrics } \\
\text { diagnoses } \\
\text { - Median age, } 4.5 \text { years } \\
\text { - Oral intake allowed }\end{array}$ & $\begin{array}{l}\text { - No difference between groups in } \mathrm{Na} \\
<135 \mathrm{mmol} / \mathrm{L} \text { at } 48 \text { hours and } 24 \\
\text { hours } \\
\text { - No increases in hypernatraemia or } \\
\text { fluid overload (eg, hypertension, } \\
\text { oedema, weight gain) }\end{array}$ & $\begin{array}{l}\text { - Bias: no } \\
\text { - Imprecision: yes } \\
\text { - Indirectness: no } \\
\text { - Final GRADE evidence level: } 3\end{array}$ \\
\hline $\begin{array}{l}\text { McNab et al, } 2015 \text { PIMS } \\
\text { study } \\
\text { - Children's hospital, } \\
\text { Melbourne, Australia } \\
\text { - } \mathrm{n}=676\end{array}$ & $\begin{array}{l}\text { 1. Plasma-Lyte } 148 / 5 \% \mathrm{D} \\
\text { 2. } 0.45 \% \mathrm{NaCl} / 5 \% \mathrm{D} \\
\text { - Median volume administered } \\
\text { similarly at } 80 \% \text { standard } \\
\text { rates }\end{array}$ & $\begin{array}{l}\text { - } \text { Age } 3 \text { months to } 18 \text { years } \\
\text { - Broad-range paediatrics } \\
\text { diagnoses } \\
\text { - } 46 \% \text { Surgical } \\
\text { - } 3 \% \text { ICU admission } \\
\text { - Mean treatment duration, } \\
\\
\text { 21-22 h }\end{array}$ & $\begin{array}{l}\text { - Isotonic fluid associated with lower } \\
\text { risk of hyponatraemia (OR=0.31, } \\
95 \% \mathrm{Cl}=0.16-0.61) \\
\text { - No evidence of hypernatraemia, } \\
\text { overhydration, or hyperchloraemic } \\
\text { acidosis } \\
\text { - } \mathrm{Na}<135 \mathrm{mmol} / \mathrm{L} \text { in } \sim 11 \% \text { of } \\
\text { children receiving } 0.45 \% \mathrm{NaCl}\end{array}$ & $\begin{array}{l}\text { - } \text { Bias: no } \\
\text { - Imprecision: no } \\
\text { - Indirectness: no } \\
\text { - Final GRADE evidence level: } 4\end{array}$ \\
\hline $\begin{array}{l}\text { Pemde et al, } 2015^{26} \\
\text { - Tertiary care hospital, } \\
\text { India } \\
\text { - } \mathrm{n}=92\end{array}$ & $\begin{array}{l}\text { 1. } 0.9 \% \mathrm{NaCl} / 5 \% \mathrm{D} \\
\text { 2. } 0.45 \% \mathrm{NaCl} / 5 \% \mathrm{D} \\
\text { 3. } 0.18 \% \mathrm{NaCl} / 5 \% \mathrm{D} \\
\text { - At standard rate }\end{array}$ & $\begin{array}{l}\text { - Age } 3 \text { months to } 5 \text { years } \\
\text { - CNS infections (pyogenic, } \\
\text { viral, tubercular meningitis, or } \\
\text { cerebral malaria) }\end{array}$ & $\begin{array}{l}\text { - Risk of developing hyponatraemia } \\
\text { compared with } 0.9 \% \mathrm{NaCl} \\
-\quad 6.5 \text {-fold }(95 \% \mathrm{Cl}=1.6-26) \text { in } \\
0.45 \% \mathrm{NaCl} \text { group } \\
-\quad 8.5 \text {-fold }(95 \% \mathrm{Cl}=2.16-33.39) \text { in } \\
0.18 \% \mathrm{NaCl} \text { group } \\
\text { - Longer use of hypotonic fluids } \\
\text { may increase the incidence of } \\
\text { hyponatraemia }\end{array}$ & $\begin{array}{l}\text { - } \text { Bias: no } \\
\text { - Imprecision: no } \\
\text { - Indirectness: yes } \\
\text { - Final GRADE evidence level: } 3\end{array}$ \\
\hline $\begin{array}{l}\text { Shamim et al, } 2014^{27} \\
\text { - Paediatrics ward in } \\
\text { teaching hospital, } \\
\text { India } \\
\text { - } \mathrm{n}=60\end{array}$ & $\begin{array}{l}\text { 1. } 0.18 \% \mathrm{NaCl} / 5 \% \mathrm{D} \text { at } \\
\text { standard rate } \\
\text { 2. } 0.9 \% \mathrm{NaCl} / 5 \% \mathrm{D} \text { at } 60 \% \\
\text { standard rate }\end{array}$ & $\begin{array}{l}\text { - Age } 0.5 \text { years to } 12 \text { years } \\
\text { - Enteric fever, complicated } \\
\text { malaria, or sepsis diagnoses }\end{array}$ & $\begin{array}{l}\text { - Significantly higher hyponatraemia } \\
\text { incidences in hypotonic group, } \\
\text { compared with isotonic group, at } \\
24 \mathrm{~h}(55 \% \text { vs } 24 \%) \text { and } 48 \mathrm{~h}(45 \% \\
\text { vs } 14 \%) \\
\text { - Fluid rates differed between groups }\end{array}$ & $\begin{array}{l}\text { - Bias: yes } \\
\text { - Imprecision: yes } \\
\text { - Indirectness: yes } \\
\text { - Final GRADE evidence level: } 2\end{array}$ \\
\hline $\begin{array}{l}\text { Golshekan et al, } 2016^{28} \\
\text { - Children's hospital, } \\
\text { Iran } \\
\text { - } \mathrm{n}=72\end{array}$ & $\begin{array}{l}\text { 1. } 20 \mathrm{~mL} / \mathrm{kg} 0.9 \% \mathrm{NaCl} \text { bolus } \\
\text { prn }+0.45 \% \mathrm{NaCl} \text { for deficit } \\
\text { and maintenance } \\
\text { 2. } 20 \mathrm{~mL} / \mathrm{kg} 0.9 \% \mathrm{NaCl} \text { prn }+ \\
0.9 \% \mathrm{NaCl}\end{array}$ & $\begin{array}{l}\text { - Age } 6 \text { months to } 14 \text { years } \\
\text { - Gastroenteritis } \\
\text { Rate and no. of received } \\
\text { boluses not mentioned }\end{array}$ & $\begin{array}{l}\text { - No difference of mean } \mathrm{Na} \text { at } 0,4 \text {, } \\
\text { and } 24 \text { hours } \\
\text { - In patients with baseline } \\
\text { hyponatraemia: } 0.9 \% \mathrm{NaCl} \text { but not } \\
0.45 \% \mathrm{NaCl} \text { significantly improved } \\
\text { hyponatraemia at } 4 \text { and } 24 \text { hours }\end{array}$ & $\begin{array}{l}\text { - Bias: yes } \\
\text { - Imprecision: yes } \\
\text { - Indirectness: no } \\
\text { - Final GRADE evidence level: } 3\end{array}$ \\
\hline $\begin{array}{l}\text { Flores Robles et al, } \\
2016^{29} \\
\text { - Paediatrics general } \\
\text { and emergency ward, } \\
\text { regional hospital, } \\
\text { Mexico } \\
\text { - } \mathrm{n}=151\end{array}$ & $\begin{array}{l}\text { 1. } 0.3 \% \mathrm{NaCl} / 3.3 \% \mathrm{D} \\
\text { 2. } 0.45 \% \mathrm{NaCl} / 5 \% \mathrm{D} \\
\text { 3. } 0.9 \% \mathrm{NaCl} / 5 \% \mathrm{D} \\
\text { - At standard rate }\end{array}$ & $\begin{array}{l}\text { - Age } 3 \text { months to } 15 \text { years } \\
\text { - } 70 \% \text { medical, } 30 \% \text { surgical } \\
\text { - Included patients with } \\
\text { dehydration in whom } 50 \% \text { of } \\
\text { the deficit was replaced in } 8 \mathrm{~h}\end{array}$ & $\begin{array}{l}\text { - Both hypotonic fluids significantly } \\
\text { increased risks of hyponatraemia } \\
\text { and hospital-acquired } \\
\text { hyponatraemia } \\
\text { - Mean chloride level at T8 } \\
\text { significantly higher in } 0.9 \% \mathrm{NaCl} \\
\text { (105.5 mmol/L) group than in } \\
\text { hypotonic fluids group } \\
\text { - No differences in hypernatraemia, } \\
\text { oedema, hypertension, or renal } \\
\text { function }\end{array}$ & $\begin{array}{l}\text { - Bias: no } \\
\text { - Imprecision: no } \\
\text { - Indirectness: no } \\
\text { - Final GRADE evidence level: } 4\end{array}$ \\
\hline $\begin{array}{l}\text { Torres et al, } 2019^{30} \\
\text { - Paediatrics ward } \\
\text { in general hospital, } \\
\text { Buenos Aires, } \\
\text { Argentina } \\
\text { - } \mathrm{n}=299\end{array}$ & $\begin{array}{l}\text { 1. } 0.45 \% \mathrm{NaCl} \text { in } 5 \% \mathrm{D} \\
\text { 2. Isotonic fluid ( } \mathrm{Na} 128 \mathrm{mmol} / \mathrm{L}) \\
\text { - At standard rate }\end{array}$ & $\begin{array}{l}\text { - Age } 29 \text { days to } 15 \text { years in } \\
\text { PICU and }>6 \text { years in general } \\
\text { ward } \\
\text { - } 12 \% \text { oncology, } 27 \% \\
\text { postoperative, } 40 \% \\
\text { respiratory illness }\end{array}$ & $\begin{array}{l}\text { - At } 24 \text { hours, high risk of } \\
\text { hyponatraemia in hypotonic group } \\
\text { (RR=3.7, } 95 \% \mathrm{Cl}=2.3-5.9) \\
\text { - No hypernatraemia }(\mathrm{Na}>150 \\
\mathrm{mEq} / \mathrm{L}) \\
\text { - No difference in no. of patients with } \\
\text { acidosis ( } \mathrm{pH}<7.30) \text {, serum } \mathrm{pH} \text { and } \\
\text { serum bicarbonate }\end{array}$ & $\begin{array}{l}\text { - Bias: yes } \\
\text { - Imprecision: no } \\
\text { - Indirectness: some } \\
\text { - Final GRADE evidence level: } 3\end{array}$ \\
\hline $\begin{array}{l}\text { Bagri et al, } 2019^{31} \\
\text { - Paediatrics ward in } \\
\text { teaching hospital, } \\
\text { India } \\
\text { - } \mathrm{n}=150\end{array}$ & $\begin{array}{l}\text { 1. } 0.45 \% \mathrm{NaCl} / 5 \% \mathrm{D} \\
\text { 2. } 0.9 \% \mathrm{NaCl} / 5 \% \mathrm{D} \\
\text { - At standard rates } \\
\text { - Oral intake not adjusted }\end{array}$ & $\begin{array}{l}\text { - Age } 1 \text { month to } 18 \text { years } \\
\text { - Wide range of CNS } \\
\text { diagnoses (encephalitis } \\
\text { or meningitis), respiratory } \\
\text { illnesses, few gastrointestinal } \\
\text { diagnoses, malignancy } \\
\text { - High mortality rate }\end{array}$ & $\begin{array}{l}\text { - Incidences of hyponatraemia were } \\
\text { similar in } 0.9 \% \text { and } 0.45 \% \mathrm{NaCl} \\
\text { groups } \\
\text { - More patients with hypernatraemia } \\
\text { in } 0.9 \% \mathrm{NaCl} \text { group (3; highest level, } \\
161 \mathrm{mmol} / \mathrm{L}) \text { than in } 0.45 \% \mathrm{NaCl} \\
\text { group }(1 ; \text { highest level, } 151 \mathrm{mmol} / \mathrm{L})\end{array}$ & $\begin{array}{l}\text { - Bias: yes } \\
\text { - Imprecision: yes } \\
\text { - Indirectness: yes } \\
\text { - Final GRADE evidence level: } 2\end{array}$ \\
\hline $\begin{array}{l}\text { Kumar et al, } 2020^{32} \\
\text { - Tertiary care hospital, } \\
\text { Delhi, India } \\
\text { - } \mathrm{n}=168\end{array}$ & $\begin{array}{l}\text { 1. } 0.45 \% \mathrm{NaCl} / 5 \% \mathrm{D} \\
\text { 2. } 0.9 \% \mathrm{NaCl} / 5 \% \mathrm{D} \\
\text { - At standard rates } \\
\text { - Oral intake not adjusted }\end{array}$ & $\begin{array}{l}\text { - Age } 3 \text { months to } 5 \text { years } \\
\text { - Wide range of respiratory, } \\
\text { CNS, gastrointestinal, } \\
\text { metabolic disease, and } \\
\text { poisoning diagnoses }\end{array}$ & $\begin{array}{l}\text { - Incidence of hyponatraemia at } \\
24 \text { hours lower in isotonic fluids } \\
\text { group, but difference was not } \\
\text { statistically significant }(P=0.08) \\
\text { - No differences in terms of } \\
\text { hypernatraemia or fluid overload }\end{array}$ & $\begin{array}{l}\text { - } \text { Bias: no } \\
\text { - Imprecision: yes } \\
\text { - Indirectness: no } \\
\text { - Final GRADE evidence level: } 3\end{array}$ \\
\hline
\end{tabular}

Abbreviations: 95\% Cl = 95\% confidence interval; CNS = central nervous system; $D=$ dextrose; ICU = intensive care unit; IVF = intravenous fluid; NaCl = sodium chloride; $\mathrm{OR}=$ odds ratio; $\mathrm{PICU}=$ paediatric intensive care unit; $\mathrm{prn}=$ pro re nata; $\mathrm{RR}=$ relative risk 
Statement 6. Calculations of maintenance IVF rate should include all oral, enteral, drug, and blood products, normally using the Holliday-Segar formula. Patients at risk of SIADH may require fluid restriction. (Consensus)

Traditionally, daily IVF volumes should be calculated using the Holliday-Segar formula. However, evidence regarding appropriate fluid volumes in hospitalised children is lacking. McNab et $\mathrm{al}^{35}$ examined four (mostly surgical) RCTs which included restricted rates in their intervention arms. The limited evidence available ${ }^{36,37}$ showed that $0.45 \% \mathrm{NaCl}$ at $<70 \%$ maintenance rates did not protect against hyponatraemia, suggesting that fluid type is more important than fluid rate for prevention of hyponatraemia.

The IVFWG has these consensus opinions, pending more evidence:

6.1 When determining fluid volumes, volumes calculated using the Holliday-Segar formula should rarely exceed adult volumes $(2 \mathrm{~L} /$ day for girls and $2.5 \mathrm{~L} /$ day for boys) or $100 \mathrm{~mL} /$ hour. $^{3}$ In patients for whom accurate calculation of insensible water loss is important (eg, patients with obesity, acute kidney injury, chronic kidney disease, or cancer), body surface area may be useful when calculating fluid requirements at 300 to $400 \mathrm{~mL} / \mathrm{m}^{2} / 24$ hours plus urine output ${ }^{3}$; or in patients weighing $>10 \mathrm{~kg}$, fluid requirements calculated as $1500 \mathrm{~mL} / \mathrm{m}^{2} / 24$ hours. ${ }^{38}$

Importantly, clinicians should not prescribe maintenance IVF at rates above the calculated maintenance rate.

6.2 In patients at risk of SIADH (Table 3), volumes may be restricted to $60 \%$ to $80 \%$ maintenance. Patients with central nervous system conditions (eg, meningitis, encephalitis, or major head injury) may require fluid restriction to $50 \%$ for management of cerebral oedema.

\section{Statement 7. Ongoing fluid loss should be replaced using fluids with comparable electrolyte compositions. (Consensus)}

7.1 Increased ongoing losses (eg, vomiting, diarrhoea, ostomy, and third space losses) should be taken into account and replaced with comparable fluids (Table $5^{3,9,10,39,40}$ shows electrolyte compositions of various body fluids). For vomiting and non-choleric diarrhoea, both $0.45 \% \mathrm{NaCl}$ or $0.9 \% \mathrm{NaCl}$ solutions (with added potassium) are recommended.

7.2 Abnormal urine electrolyte losses can vary widely; thus, monitoring of paired urine and serum electrolyte levels, as well as creatinine and osmolarity parameters, may be needed. In some situations, even isotonic fluids may be insufficient to prevent hyponatraemia (eg, patients with central nervous system injury with cerebral salt wasting or patients with SIADH in whom urine osmolality is $>500 \mathrm{mOsmol} / \mathrm{kg}$ ); these patients require measurement of urinary electrolytes and osmolality.

\section{Statement 8. All children receiving IVF} should undergo regular clinical and biochemical monitoring to assess their responses to therapy and changes in clinical status. Monitoring frequencies should be based on a risk assessment involving the child's age, clinical and volume statuses, stability, IVF proportion, and presence of biochemical abnormalities. (Consensus)

8.1 An infusion pump should be used for all children requiring maintenance IVF.

8.2 Children receiving IVF should have an accurate weight recorded on admission or as soon as clinically possible; daily weight should be recorded as needed, specifically noting weight fluctuations $\pm 3 \%$ in 24 hours. Daily fluid balance (ie, input, output, and abnormal ongoing loss) should be recorded.

8.3 Clinical assessment of fluid status (ie, body weight, heart rate, capillary refill time, hydration, and blood pressure), fluid balance, oral fluid tolerance, and the continued need for IVF should be reviewed often (preferably at least twice daily).

8.4 The plasma electrolyte profile (sodium, potassium, urea, creatinine, chloride, and acid-

TABLE 5. Electrolyte compositions of various fluids (modified from NICE ${ }^{3}, \mathrm{Kaptein}^{39}, \mathrm{CHOP}$ IVF clinical pathway ${ }^{40}$ )

\begin{tabular}{lcccc}
\hline Fluid & $\mathbf{N a}^{+}(\mathbf{m E q} / \mathbf{L})$ & $\mathbf{K}^{+}(\mathbf{m E q} / \mathbf{L})$ & $\mathbf{C l}^{-}(\mathbf{m E q} / \mathbf{L})$ & $\begin{array}{c}\text { Suggested replacement fluid: with } \\
\text { added KCl }\end{array}$ \\
\hline Gastric & $20-80$ & $5-20$ & $100-150$ & $0.45 \% \mathrm{NaCl}^{9,10}$ or $0.9 \% ~ \mathrm{NaCl}^{3}$ \\
Pancreatic & $120-140$ & $5-15$ & $90-120$ & $0.9 \% \mathrm{NaCl}$ \\
Small bowel & $100-140$ & $5-15$ & $90-130$ & $0.9 \% \mathrm{NaCl}$ \\
Bile & $120-140$ & $5-15$ & $80-120$ & $0.9 \% \mathrm{NaCl}$ \\
lleostomy & $45-135$ & $3-15$ & $20-115$ & $0.9 \% \mathrm{NaCl}$ \\
Diarrhoea (non-cholera) & $10-90$ & $10-80$ & $10-110$ & $0.45 \% \mathrm{NaCl}^{9,10}$ or $0.9 \% \mathrm{NaCl}^{3}$ \\
\hline
\end{tabular}

Abbreviations: $\mathrm{Cl}^{-}=$chloride; $\mathrm{K}^{+}=$potassium; $\mathrm{KCl}=$ potassium chloride; $\mathrm{Na}^{+}=$sodium; $\mathrm{NaCl}=$ sodium chloride 
base level) should be checked at the initiation of IVF, then rechecked in accordance with the risk level and proportion of maintenance fluid supplied as IVF. In young infants, highrisk patients, and patients receiving prolonged IVF treatment, reassessments should be performed at least daily or more frequently if an electrolyte abnormality is present, or if the patient is particularly unwell. The blood glucose level should be checked if there is a risk of hypoglycaemia (eg, in young infants). Paired serum and urinary osmolarity and electrolyte profiles may be useful to guide fluid prescription in patients with electrolyte abnormalities.

\section{Conclusion}

While there is strong evidence that isotonic solutions are the most appropriate maintenance IVF for the vast majority of hospitalised children, a reflexive approach to IVF prescription should be avoided. Intravenous fluid should be prescribed with the same care used for medications; with the rate and type of fluid tailored to the individual's clinical and pathophysiological statuses. Regular monitoring and reassessment with appropriate fluid readjustment are critical considerations. Many aspects of IVF treatment continue to exhibit a lack of evidence, such as the selection of $0.9 \%$ $\mathrm{NaCl}$ or balanced solution, as well as the fluid rate and optimal potassium supplement composition. When more evidence is available, these practice statements with the accompanying algorithms should be reviewed.

\section{Author contributions}

Concept or design: LCK Leung, KC Chan.

Acquisition of data: LCK Leung.

Analysis or interpretation of data: All authors.

Drafting of the manuscript: LCK Leung.

Critical revision of the manuscript for important intellectual content: All authors.

All authors had full access to the data, contributed to the study, approved the final version for publication, and take responsibility for its accuracy and integrity.

\section{Conflicts of interest}

All authors have disclosed no conflicts of interest.

\section{Acknowledgement}

The authors would like to thank reviewers of the Intravenous Fluid Clinical Pathway (Dr KW Hung, Dr YW Kwan, Dr SN Wong, Dr SWC Wong, and Dr MM Yau) for their invaluable comments.

\section{Funding/support}

This study received no specific grant from any funding agency in the public, commercial, or not-for-profit sectors.

\section{References}

1. Holliday MA, Segar WE. The maintenance need for water in parenteral fluid therapy. Pediatrics 1957;19:823-32.

2. Koczmara C, Wade AW, Skippen P, et al. Hospital-acquired acute hyponatremia and reports of pediatric deaths. Dynamics 2010;21:21-6.

3. National Institute for Health and Care Excellence. Intravenous fluid therapy in children and young people in hospital. NICE guideline [NG29]. December 2015. Available from: https://www.nice.org.uk/guidance/ng29. Accessed 2 Jul 2019.

4. Feld LG, Neuspiel DR, Foster BA, et al. Clinical practice guideline: maintenance intravenous fluids in children. Pediatrics 2018;142:e20183083.

5. Leung LC, Chan KC, Chan WK, et al. Hyponatraemia in hospitalized children: a retrospective survey in acute paediatric admissions in Hong Kong with focus on intravenous fluid practices. HK J Paediatr (New Series) 2020;25:137-47.

6. Hoorn EJ. Intravenous fluids: balancing solutions. J Nephrol 2017;30:485-92.

7. Semler MW, Self WH, Wanderer JP, et al. Balanced crystalloids versus saline in critically ill adults. N Engl J Med 2018;378:829-39.

8. Raghunathan K, Shaw A, Nathanson B, et al. Association between the choice of IV crystalloid and in-hospital mortality among critically ill adults with sepsis. Crit Care Med 2014;42:1585-91.

9. Self WH, Semler MW, Wanderer JP, et al. Balanced crystalloids vs saline in noncritically ill adults. N Engl J Med 2018;378:819-28.

10. Wilcox CS. Regulation of renal blood flow by plasma chloride. J Clin Invest 1983;71:726-35.

11. Stenson EK, Cvijanovich NZ, Anas N, et al. Hyperchloremia is associated with complicated course and mortality in pediatric patients with septic shock. Pediatr Crit Care Med 2018;19:155-60.

12. Barhight MF, Lusk J, Brinton J, et al. Hyperchloremia is independently associated with mortality in critically ill children who ultimately require continuous renal replacement therapy. Pediatr Nephrol 2018;33:1079-85.

13. Emrath ET, Fortenberry JD, Travers C, McCracken CE, Hebbar KB. Resuscitation with balanced fluids is associated with improved survival in pediatric severe sepsis. Crit Care Med 2017;45:1177-83.

14. Moritz ML, Ayus JC. Maintenance intravenous fluids in acutely ill patients. N Engl J Med 2015;373:1350-60.

15. Ministry of Health, New South Wales Government. Infants and children: Management of acute gastroenteritis. 4th ed. Available from: https://www1.health.nsw.gov.au/pds/ ActivePDSDocuments/GL2014_024.pdf. Accessed 2 Jul 2019.

16. Guarino A, Ashkenazi S, Gendrel D, et al. European Society for Pediatric Gastroenterology, Hepatology, and Nutrition/European Society for Pediatric Infectious Diseases evidence-based guidelines for the management of acute gastroenteritis in children in Europe: update 2014. J Pediatr Gastroenterol Nutr 2014;59:132-52.

17. Iro MA, Sell T, Brown N, Maitland K. Rapid intravenous rehydration of children with acute gastroenteritis and dehydration: a systematic review and meta-analysis. BMC Pediatr 2018;18:44.

18. Sümpelmann R, Becke K, Crean P, et al. European 
consensus statement for intraoperative fluid therapy in children. Eur J Anaesthesiol 2011;28:637-90.

19. Sümpelmann R, Becke K, Zander R, Witt L. Perioperative fluid management in children: can we sum it all up now? Curr Opin Anesthesiol 2019;32:384-91.

20. Mahajan V, Sajan SS, Sharma A, Kaur J. Ringer's lactate vs normal saline for children with acute diarrhea and severe dehydration-a double blind randomized controlled trial. Indian Pediatr 2012;49:963-8.

21. Kartha GB, Rameshkumar R, Mahadevan S. Randomized double-blind trial of ringer lactate versus normal saline in pediatric acute severe diarrheal dehydration. J Pediatr Gastroenterol Nutr 2017;65:621-6.

22. Fuhrman DY, Kellum JA. Hyperchloremic IV solutions: have we seen enough?...or "still good medicine?" Pediatr Crit Care Med 2018;19:171-2.

23. Kannan L, Lodha R, Vivekanandhan S, Bagga A, Kabra SK, Kabra M. Intravenous fluid regimen and hyponatraemia among children: a randomized controlled trial. Pediatr Nephrol 2010;25:2303-9.

24. Friedman JN, Beck CE, DeGroot J, et al. Comparison of isotonic and hypotonic intravenous maintenance fluids: a randomized clinical trial. JAMA Pediatr 2015;169:445-51.

25. McNab S, Duke T, South M, et al. $140 \mathrm{mmol} / \mathrm{L}$ of sodium versus $77 \mathrm{mmol} / \mathrm{L}$ of sodium in maintenance intravenous fluid therapy for children in hospital (PIMS): a randomised controlled double-blind trial. Lancet 2015;385:1190-7.

26. Pemde HK, Dutta AK, Sodani R, Mishra K. Isotonic intravenous maintenance fluid reduces hospital acquired hyponatremia in young children with central nervous system infections. Indian J Pediatr 2015;82:13-8.

27. Shamim A, Afzal K, Ali SM. Safety and efficacy of isotonic $(0.9 \%)$ vs. hypotonic $(0.18 \%)$ saline as maintenance intravenous fluids in children: a randomized controlled trial. Indian Pediatr 2014;51:969-74.

28. Golshekan K, Badeli H, Miri M, et al. Suitable intravenous fluid for preventing dysnatremia in children with gastroenteritis: a randomized clinical trial. J Renal Inj Prev 2016;5:69-73.

29. Flores Robles CM, Cuello Garcia CA. A prospective trial comparing isotonic with hypotonic maintenance fluids for prevention of hospital-acquired hyponatraemia. Paediatr Int Child Health 2016;36:168-74.

30. Torres SF, Iolster T, Schnitzler EJ, et al. Hypotonic and isotonic intravenous maintenance fluids in hospitalised paediatric patients: a randomised controlled trial. BMJ Paediatr Open 2019;3:e000385.

31. Bagri NK, Saurabh VK, Basu S, Kumar A. Isotonic versus hypotonic intravenous maintenance fluids in children: a randomized controlled trial. Indian J Pediatr 2019;86:10116.

32. Kumar M, Mitra K, Jain R. Isotonic versus hypotonic saline as maintenance intravenous fluid therapy in children under 5 years of age admitted to general paediatric wards: a randomised controlled trial. Paediatr Int Child Health 2020;40:44-9.

33. Children's Hospital Colorado. Clinical pathway: intravenous fluid therapy. Available from: https:// www.childrenscolorado.org/globalassets/healthcareprofessionals/clinical-pathways/intravenous-fluidtherapy.pdf. Accessed 25 May 2020.

34. Weinberg L, Collins N, Van Mourik K, Tan C, Bellomo R. Plasma-Lyte 148: a clinical review. World J Crit Care Med 2016;5:235-50.

35. McNab S, Ware RS, Neville KA, et al. Isotonic versus hypotonic solutions for maintenance intravenous fluid administration in children. Cochrane Database Syst Rev 2014;(12):CD009457.

36. Yung M, Keeley S. Randomised controlled trial of intravenous maintenance fluids. J Paediatr Child Health 2009;45:9-14.

37. Neville KA, Sandeman DJ, Rubinstein A, Henry GM, McGlynn M, Walker JL. Prevention of hyponatremia during maintenance intravenous fluid administration: a prospective randomized study of fluid type versus fluid rate. J Pediatr 2010;156:313-9.e1-2.

38. Engorn B, Flerlage J, editors. The Harriet Lane Handbook: A Manual for Pediatric House Officers 20th ed. Philadelphia (PA): Elsevier; 2015: 248.

39. Kaptein EM, Sreeramoju D, Kaptein JS, Kaptein MJ. A systematic literature search and review of sodium concentrations of body fluids. Clin Nephrol 2016;86:20328.

40. Children's Hospital of Philadelphia. Inpatient clinical pathway for children who require continuous administration of IV fluids. Available from: https:// www.chop.edu/clinical-pathway/fluid-administrationcontinuous-iv-clinical-pathway. Accessed 25 May 2020. 